\title{
Platelet Count 50000
}

National Cancer Institute

\section{Source}

National Cancer Institute. Platelet Count 50000. NCI Thesaurus. Code C53267.

Indicates a platelet count of at least 50,000 per cubic millimeter. 